\title{
Research on the Path of Reverse Innovation: A Case Study of High-tech Industry Latecomer Firms in China
}

\author{
Xiaomei Han", Shanshan Liu \\ School of Economics and Management, China University of Petroleum (East China), Qingdao, P. R. China \\ Email address: \\ han.xiaomei@foxmail.com (Xiaomei Han), upcliushanshan@163.com (Shanshan Liu) \\ ${ }^{*}$ Corresponding author
}

\section{To cite this article:}

Xiaomei Han, Shanshan Liu. Research on the Path of Reverse Innovation: A Case Study of High-tech Industry Latecomer Firms in China. International Journal of Economics, Finance and Management Sciences. Vol. 8, No. 4, 2020, pp. 138-145. doi: 10.11648/j.ijefm.20200804.12

Received: June 24, 2020; Accepted: July 14, 2020; Published: July 22, 2020

\begin{abstract}
With the economic slowdown in developed countries and the rise of emerging economies, reverse innovation from developing countries has had a profound impact on the global changes of multinational companies. As a global innovation diffusion model, it plays a vital role in the late stage of company innovation catch-up. Reverse innovation is about to become an important means to international competition, so exploring how to effectively carry out and implement reverse innovation is of great guiding value to the management practice of multinational companies. First of all, this article reviews the relevant literature on reverse innovation and introduces the research status of this topic. Based on this, through a vertical case study of three representative companies in China's high-tech industry (Huawei, Galanz and Mindray), the article explores the innovation and development process of their products from three stages of imitation innovation, independent innovation and leading technology, and summarizes the three companies in reverse innovation success path. Finally, according to the successful experience of the case, the article puts forward suggestions to promote the development of high-tech enterprises from three aspects of expanding emerging markets, improving independent innovation ability and actively using policy resources, providing reference and inspiration for enterprises to improve innovation ability and accelerate internationalization process.
\end{abstract}

Keywords: Emerging Markets, Latecomers, Reverse Innovation

\section{Introduction}

Innovation is no longer just a privilege that high-income countries can enjoy alone. It has achieved globalization. Innovative globalization is a means for the country to acquire capabilities that are lacking abroad [1]. However, enterprise innovation in developing countries is different from Western companies [2]. As global investment and growth patterns gradually change. Multinational companies from emerging markets are becoming increasingly important [3].

Emerging countries, such as China and India, have been regarded as the cradle of innovation [4]. The rise of the giants of China, India and Brazil, in the second phase of the globalization process and the impressive expansion of the middle class [5], has brought new huge markets to multinational corporations (MNCs). In this era, China has become a significant new market, and $62 \%$ of multinational companies are more willing to establish $\mathrm{R} \& \mathrm{D}$ centers in China [6]. Because China not only represents more than 300 million consumers [7] but is also attractive to multinational companies in advanced economies, multinational companies believe that the prospects for emerging market countries are much better than Western Europe and the United States [8].

The background of reverse innovation is that emerging market economies are transforming into innovation centers, and the fiercely competitive environment forces multinational companies to innovate continuously to maintain and survive [9]. They turned their attention to emerging markets so that they could formulate future growth plans. This can facilitate the potential of these rapidly changing markets [10]. After understanding the complexity of emerging markets, the company adjusts its development strategy. The company develops specific products and adapts the products to local needs and realities. After this, these innovative products have returned to high-income countries [11]. Therefore, reverse innovation is first completed and promoted in developing countries [12], and then spread to developed countries [13]. On the one hand, reverse 
innovation can help multinational companies in developed countries solve the problem of sustainable growth [14].

On the other hand, reverse innovation can also have spillover effects on developing countries. It can enable companies to successfully catch up with technology [15]. It can also obtain huge profits through reverse innovation [16], which is a new development to build the core competitiveness of enterprises [17]. Therefore, multinational enterprises in emerging market countries have their unique advantages, and their reverse innovation activities have research value [18]. Reverse innovation has also gradually become a strategic topic of common concern for academics and businesses $[18,19]$.

Moreover, China is the most dynamic emerging economy today. As more and more outstanding local enterprises challenge the markets of developed countries, reverse innovation will become an essential means of competition towards internationalization. Therefore, the article must conduct in-depth research on reverse innovation.

As an emerging research field, scholars are still in the initial stage of reverse innovation. Moreover, the existing researches are mostly focused on the definition of the concept of reverse innovation and case studies with multinational companies in developed countries as the main body of research. Research rarely involves analyzing reverse innovation from the perspective of emerging markets or combining local companies in emerging markets as a case study. Based on this, based on summarizing relevant literature, this paper selects the following three representatives of Chinese high-tech multinational companies as typical research cases of reverse innovation, such as Huawei Technologies Co., Ltd. (Huawei), Guangdong Galanz Group Co. Ltd.(Galanz) and Shenzhen Mindray Biomedical Electronics Co., Ltd. (Mindray Medical). Through the above three cases, this article discuss longitudinally from various stages of the company's development how to carry out and carry out reverse innovation effectively. This is not only a useful supplement to the current academic research on international business, but also another extension and expansion of research on reverse innovation, and it also has essential guiding value for the management practice of multinational companies.

\section{Theory}

\subsection{Definition and Connotation of Reverse Innovation}

In this study, innovation refers to new or significantly improved products (including commodities, services, work processes), new marketing methods, and new organizational methods formed within the company's internal and external working relationships or other working relationships [20]. Based on this, innovation itself is embedded in the environment it is in, with specific environmental and institutional attributes [21]. Through the continuous research and development of scholars at home and abroad, the theories about innovation are becoming more and more abundant after CEO Jeffery. Immelt and Tuck School of Business scholar V. In the in-depth analysis of GM's case conducted by Govindarajan, the concept of "reverse innovation" was first proposed [22].

Existing research on reverse innovation has reached a consensus that the flow of innovation is "reverse," that is, from the market of developing countries to the market of developed countries [19]. Govindarajan and Trimble (2012) believe that reverse innovation can only be achieved when there is a gap between developed and developing countries, including technical performance requirements, infrastructure conditions, attitudes towards sustainable development, domestic laws and regulations, and domestic consumption Preference [23]. Govindarajan and Ramamurti (2011) summarized five reasons for reverse innovation. The primary manifestation is that there is a price-sensitive market in developed countries, and price reductions promote demand growth [24]. Individual consumers in developed countries often have various new characteristics. Reverse innovation is disruptive innovation from emerging markets to developed markets. It can bring advantages through technological breakthroughs. Because "Reverse Innovation" is a relatively new concept, its connotation is continually being revised due to continuous research. There are many similarities and differences with other emerging market innovations studied by previous scholars, such as innovation at the bottom of the pyramid, frugal innovation, and disruptive innovation. See Table 1 for specific differences. Simone and Alberto (2014) made a comparative analysis of reverse innovation and destructive innovation and believed that destructive innovation could be regarded as a particular case of reverse innovation [25]. MARC and Stephan (2014) analyzed the similarities and differences of cost innovation, inclusive innovation, frugal innovation and reverse innovation. They believe that as long as the geographic dimension is increased from the aftermarket to the first market, they may become reverse innovations [26]. Research data shows that about half of cost innovation, frugal innovation, and full innovation can be transformed into reverse innovation.

Table 1. Comparison of reverse innovation and other emerging market innovation concepts.

\begin{tabular}{llll}
\hline Comparative dimension & Reverse innovation & BOP innovation & Frugal innovation \\
\hline Target customers & $\begin{array}{l}\text { Low- and middle-income } \\
\text { groups }\end{array}$ & Poor people & $\begin{array}{l}\text { Low- and } \\
\text { middle-income groups }\end{array}$ \\
Main body of innovation & $\begin{array}{l}\text { Multinational companies } \\
\text { Emerging and Developed }\end{array}$ & Multinational companies & Local companies \\
Involved Markets & Markets & Emerging Markets & Emerging Markets \\
Innovation focus & Diffusion path & Target object & Peveloped Market Internal \\
\hline
\end{tabular}




\begin{tabular}{llll}
\hline Comparative dimension & Reverse innovation & BOP innovation & Frugal innovation \\
\hline Dominant logic & Reverse flow & Equality and tolerance & Cost-effective \\
\hline
\end{tabular}

Sources: Xing Xiaoqiang, Ge Hufei and Tong Yunhuan, 2016; Wei Jinde, 2017 [27, 28].

Historically, the classic innovation theory holds that developed countries are generally considered to be the dominant market and the proliferation of new products from developed countries to underdeveloped markets [12]. Reverse innovation is the same as classic innovation. On the one hand, it represents a "new combination" of production factors and production conditions in the realization process, which helps promote the development of enterprises and their social productivity. However, the initial target consumer group of reverse innovation is the ULM market group in emerging countries, which emphasizes technological and market innovation for this specific market demand. The specific differences between classic innovation and reverse innovation are shown in Table 2.

On the other hand, although reverse innovation initially focused on how to profit from the environment of emerging markets (especially the ULM market) and how to attract the attention of emerging market companies and developed market companies, reverse innovation only addresses the ULM market as an innovative problem. The source of the program focuses on the use of locally produced products to meet the needs of local people while seeking market opportunities in other emerging markets, especially developed countries.

Table 2. Comparison of innovation development process between developed and emerging countries.

\begin{tabular}{|c|c|c|}
\hline Characteristics & Classic Innovation Theory (Developed Market) & Reverse Innovation Theory (Emerging Markets) \\
\hline $\begin{array}{l}\text { Innovative launch } \\
\text { product positioning }\end{array}$ & $\begin{array}{l}\text { High-income populations in developed and developing } \\
\text { countries, then extended to low- and middle-income groups }\end{array}$ & $\begin{array}{l}\text { Emerging markets and developed markets 'marginal markets, } \\
\text { and then expanded to developed markets' mainstream markets }\end{array}$ \\
\hline Market target group & High-income group that is not price sensitive & $\begin{array}{l}\text { Low- and middle-income group that has higher requirements } \\
\text { on cost-effectiveness }\end{array}$ \\
\hline Innovation path & Developed Countries -Developing Countries & Developing Countries -Developed Countries \\
\hline $\begin{array}{l}\text { Target market } \\
\text { characteristics }\end{array}$ & $\begin{array}{l}\text { mature institutional rules, complete infrastructure } \\
\text { construction, government support, high prices and } \\
\text { performance products }\end{array}$ & $\begin{array}{l}\text { lagging institutional rules, infrastructure to be built, } \\
\text { sustainable development, limited government support, low } \\
\text { cost, strong functions, and distinctive products }\end{array}$ \\
\hline R \& D Center tendency & Developed Countries & Emerging Countries \\
\hline
\end{tabular}

Sources: Sharma and Iyer, 2012; Sharma and Jha, 2016 [29, 30].

\subsection{Research on Reverse Innovation of Enterprises}

Kent (2012) analysed many typical cases and proposed to use reverse innovation to alleviate the shortage of medical resources in the United States [31]. LIM (LIM, Han, ITO, 2013) analysed the case of Tata Corporation of India developing nano-cars and proposed to pay attention to the coordination of non-technological innovations such as technology, system, organization, and market development capabilities [32]. Ritu (2013) studied the case of rural banks [33]. Simone et al. (2014) take the Italian company Perez as an example to describe how the company solves the internal problems of Chinese organizational decision-making, and how Chinese branches design and innovate products to meet local market needs. These products have achieved success in the Chinese market and are very popular after entering the European market [34]. The case of Eugenia et al. (2017) analyses how frugal and reverse innovation can enhance sustainable development, and how to model and describe the business model in this case [35]. Fengxia (2017) and others proposed two mechanisms for analysing the product characteristics of reverse innovation and the management's reverse activation decision [36]. Ludwig (2018) uses three case studies to explain the incentives for companies in emerging economies to reverse innovation [37]. Christian (2017) conceptualized the process and practice of reverse innovation [38].

To sum up, reverse innovation firstly carries out innovation activities in developing countries, and finally transfers innovation achievements to developed countries. Scholars have also studied it but mainly based on a single case. Because single-case companies have their particularities, the conclusions are not universal. Based on the national innovation-driven strategy, this article selects three representative high-tech enterprises for a multi-case study, which has strong theoretical and practical significance. Therefore, it is of considerable significance to study the reverse innovation of these three high-tech enterprises.

\section{Methodology and Cases}

\subsection{Methodology}

Case study (CSR) is a comprehensive research strategy that is increasingly used in the study of business management [39]. Creswell defines a case study as a bounded system of time and place, where the case studied can be a procedure, event, activity, or individual [40]. Considering the typical nature of the research object and the complexity of the research topic, multiple case studies are considered to be the most appropriate method [41]. Compared with single case studies, when researchers focus on using comparative observation to promote the development of propositions, they find that the multiple case study method is suitable. It allows searching across case patterns and topics, and multiple case studies can also be compared. These comparisons can explain whether the findings are traits in nature or are consistent across multiple cases [42]. This method can maximize the 
satisfaction of the experiment, and finally reveal the common problems and topics related to the entire industry [43].

\subsection{Case Selection}

When using multiple case analysis methods to select cases, attention should be paid to the richness of case information, not the number of cases. Therefore, the selection of cases should follow the principles of typical sampling and theoretical sampling. The selected case is typical and specific, and the rich information available to the case company is a crucial consideration.

According to the principles of case typicality and data availability, when the research object of the article is determined, the following selection criteria are followed: First, the study selects that the case enterprise is a successful latecomer. The company's experience in reverse innovation has reference and reference for other local companies. Also, the case company has a relatively long experience in cooperation with overseas companies in terms of technology and business. The second is that the case company has operated and cooperated internationally for a considerable period. The company has achieved reverse innovation at different stages of development and has implemented reverse innovation of several products. The company has a relatively complete work process and rich experience in innovation management, which can provide relatively complete information; Third, the data is available. Enterprise public information is relatively abundant.

This article considers the following factors when selecting a sample of target companies: The target company's registered place in Mainland China or its business activities are mainly focused on the market expansion of Mainland China. The target company has achieved rapid growth through disruptive innovation and gradually established its leading position in the industry. The target company has a particular representative, and its success model is scalable or reproducible. The open data of the target company is easy to obtain.

Huawei, Galanz and Mindray are such typical enterprises that meet the above requirements. In the context of innovation, globalization, Huawei, Galanz and Mindray continue to embed in global innovation networks through transnational technical cooperation, overseas factory construction, joint venture mergers and acquisitions, and strategic alliances. Based on the continuous strengthening and upgrading of technology and brand, the three carry out product technology innovation according to the characteristics of local market demand. Innovative products first show undoubted competitiveness in the domestic market, and then in the international market, especially in developed markets. They quickly grew from a small business to a world-class technology company. On the other hand, selecting vertical cases for research helps to understand the strategic choices and innovative behaviors adopted by different companies in different situations, and it can more effectively test the concerns. The following describes them separately.

\section{Case Study}

\subsection{Development Status of High-tech Industry}

China's economic growth rate is among the highest in the world. For example, China achieved a GDP of 99.1 trillion yuan in 2019, an increase of $6.1 \%$ compared to last year. Among them, China's high-tech industry investment increased by $17.3 \%$ year-on-year, more than three times the overall investment growth rate [44]. In the first half of 2019, China's high-tech industry added value, and investment growth rates were above double digits. Facing the upsurge of global high-tech industry development and the coming of knowledge economy era, both developed and developing countries regard the development of high-tech and its industries as an essential basic national policy. The research and development of high-tech as the main direction of attack to develop high-tech industry and occupation of the international market are the primary goals.

China's high-tech industry has not yet reached the mid-to-high level of the global value chain. However, many excellent high-tech enterprises have achieved reverse innovation in developed countries. Moreover, it is currently the technological change cycle of high-tech industries and the economic trough cycle of developed countries. This is precisely the opportunity for China to catch up. Taking them as a case study, it gives other enterprises some inspiration to catch up and occupy the market.

\subsection{Huawei Reverse Innovation}

Since China purchased base station equipment from Europe and the United States in the 1990s to today, China's Huawei has become the world's largest provider of base station equipment. Huawei's reverse innovation path is worth exploring. This article divides Huawei's reverse innovation development path into three main stages: innovation imitation stage, independent research and development stage, and technology leading stage.

Huawei's C \& C08 conversion was his first attempt to reverse innovation. In 1987, at the stage of innovation and imitation, he began to produce PBX as an agent. He followed the product strategy of "introducing products and promoting domestically," understanding the structure of imported PBXs, using different mature technical frameworks, and replacing some parts with domestic ones for localization. To achieve independent research and development in 1989, taking into account the characteristics of social conditions, based on the absorption of expert opinions. The Huawei innovation team rejected the technical solutions of multinational companies. Huawei chose optical fiber with quasi-SDH technology as the connection method to connect the remote operation module of the switch central control, and provided an adequate protection solution). Huawei launched the rural digital switching solution in 1992. This kind of technology product that is easy to operate and can be mastered by the audience without too much training quickly became popular in the rural market. In 1994, Huawei successfully developed the C 
\& C08 switch independently and entered Hong Kong through cooperation with Hutchison Telecom (one of the most developed regions in the world). In 1996, Huawei introduced IBM's product integration development and integrated supply chain management model, which rapidly improved the functions of C \& C08. In 1997, in response to the prepaid market demand, Huawei implemented customized business processes and billing methods on $\mathrm{C} \& \mathrm{C} 08$ machines. In 1998, Huawei launched 128-module C \& C08, which improved integration and scalability. In 2000, Huawei achieved technological leadership. Through cooperation with companies such as $3 \mathrm{Com}$ and Siemens, Huawei has opened the European and American markets and realized the transition of technology from emerging developing countries to developed countries.

Huawei attaches great importance to technological innovation and research and insists on investing more than $10 \%$ of its annual income in research and development. In 2018, Huawei invested more than 100 billion yuan in research and development, ranking fifth in the world in the "EU Industrial R \& D Investment Ranking 2018". In 2018, the company had more than $80,000 \mathrm{R}$ \& $\mathrm{D}$ personnel, accounting for approximately $45 \%$ of the company's total number. R \& D expenditure was 101.509 billion-yuan, accounting for approximately $14.1 \%$ of annual revenue. Behind the high $\mathrm{R}$ \& D investment, Huawei's emphasis on innovation and technology is more reflected. At the same time, Huawei has achieved remarkable results with its high R \& D investment. Huawei's patented technology has ranked among the top patent applications for many consecutive years. Since 2014, it has consistently ranked first, as shown in Figure 1.
This form of the base station has completely changed the traditional wireless construction model and brought about innovations in mobile network construction models and wireless base station design. At the same time, a CPRI (Public Radio Interface) cooperative organization was established with companies such as Ericsson NEC and Siemens, devoted to the standardization of baseband and radio frequency interfaces. CPRI issued more complete specifications, which promoted the maturity of standards and equipment. Huawei's technology is expanding backwards to developed markets. Huawei has always chosen to start from developing countries with relatively backward infrastructure development in telecommunications industry and low demand for product technology to establish research institutes and finally spread like developed countries, in 2003 in China and India in 1999. And Russia, Turkey in 2009, Sweden in 2000, and the opening of research institutes in European countries in 2008. Based on distributed base stations, in 2018, Huawei officially released the world's first $5 \mathrm{G}$ terminal chip based on the 3GPP standard and the first 5G CPE (customer multiplexing equipment) based on the chip. In September 2018, the three-phase test of 5G Non-Independent Networking (NSA) and Independent Networking (SA) led by the IMT-2020 (5G) Promotion Group ended. Huawei became the first vendor to complete all tests, and all the index test results are optimal. As of the end of February 2019, Huawei has signed more than $305 \mathrm{G}$ commercial contracts with leading global operators, and more than 40,000 5G base stations have been sent around the world. From distributed base stations to the realization of $5 \mathrm{G}$, it has demonstrated the success of reverse innovation.

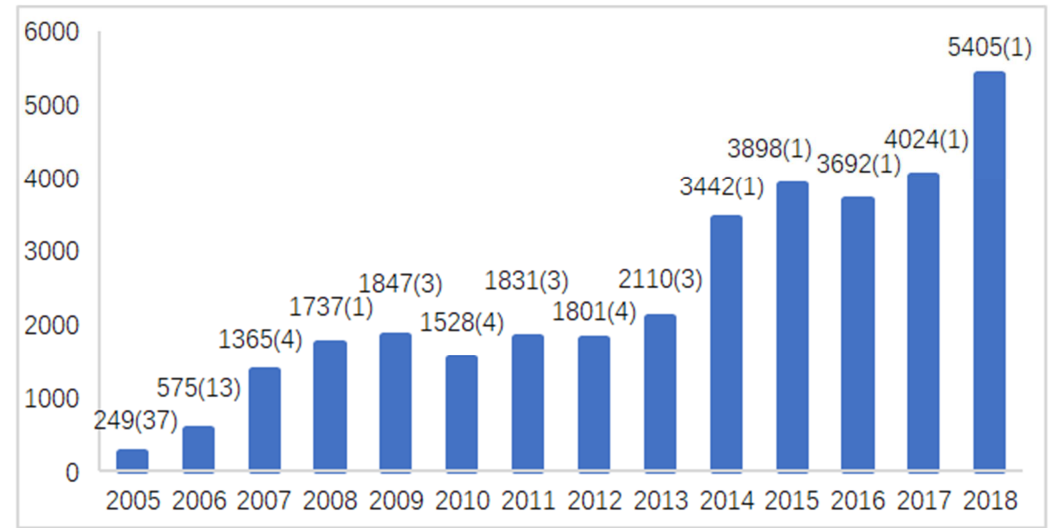

Sources: Huawei Investment Holdings Co., Ltd 2018 Annual Report, 2018.

Figure 1. The number of international patented technology and world ranking of Huawei, 2005 to 2018.

\subsection{Galanz Reverse Innovation}

It took 27 years from Galanz to enter the home appliance industry in 1992 to the world's first microwave oven manufacturing. The white goods products independently developed by Galanz have covered more than 170 countries and regions in the world, and their influence in the international home appliance market is gradually increasing.

Galanz's "Black Diamond" microwave oven is a reverse innovation product imitating the innovation stage. Galanz introduces mature and advanced technologies from abroad, carries out technological innovation and localization of parts and components. In order to further develop the market, Galanz has improved the traditional microwave oven window and designed it as a large-screen window. In 2000, Galanz University launched "Black Diamond," which is very popular in China. After studying at the American Research Center, with the help of the international marketing network, she quickly entered Notre Dame.

Galanz's convection oven and "double frequency 
conversion" microwave oven are products in the stage of independent innovation. At this stage, Galanz proposed the strategy of "world factory" to "global brand-name home appliance manufacturing center" and jointly developed new products with different $\mathrm{R} \& \mathrm{D}$ centers. It is difficult to cool the copper tubes of ordinary microwave ovens after heating, which can easily cause burns, and the quartz tubes have low thermal efficiency. In 2001, after breaking through the light wave technology, Galanz developed the world's first digital light wave microwave combination oven, setting a new standard for the microwave oven industry. Subsequently, Galanz combined with domestic cooking habits to upgrade the core component of the microwave oven, the magnetron and developed a frequency conversion microwave oven, which can freely control the strength of the fire, make the heating uniform and improve the power efficiency. The convection oven and 'double frequency conversion' microwave oven meet the needs of customers in mainstream markets at home and abroad.

Galanz's WaKOO Retro Refrigerator is a product at the leading stage of technology. As the new pillar industry of Galanz, Galanz Refrigerator leads the world in the world refrigerator market quickly and comprehensively. In 2019, Galanz maintained double-digit growth overall in North American foreign trade. The reason for this is that Galanz did not blindly follow the trend of the primary functions, concentrated on research, continued innovation, and integrated minimalist and retro aestheticism into the aesthetics of home appliances. Give a new aesthetic definition for modern appliances. In 2017, Galanz launched the $\mathrm{WaKOO}$ retro refrigerator to meet the personalization and differentiation of young consumers. In just a few years since its launch, it has been loved by many young people who pursue fashion. This series of retro refrigerators have an annual output of millions and is sold to major overseas markets such as North America, Japan, South Korea, and Western Europe under its brand.

\subsection{Mindray Reverse Innovation}

In 1991, Shenzhen Mindray Biomedical Electronics Co., Ltd. (Mindray Medical) was established. In 2000, Mindray Medical entered the overseas market. The company has established 40 overseas subsidiaries in 39 countries around the world, and its more than 230 product models meet 19 global regulatory requirements. Mindray products are exported to more than 190 countries and regions and are widely recognized in medical institutions in the United States, Britain, Germany, France, Italy, Spain and other countries. Mindray is a long-term partner of the world's top medical institutions, such as Parma Children's Hospital in Italy, RIE Hospital in the United Kingdom, Karolinska Medical School in Sweden, and CMC Vellore Hospital in India. In the first quarter of 2019, Mindray Medical continues to maintain the momentum of rapid growth. Compared with last year, the company's revenue increased by $20.69 \%$ to 3.9 billion yuan, and its profit increased by $24.59 \%$.

The all-digital black and white super is a reverse innovation product of Mindray in the imitation innovation stage. Since its establishment, Mindray Medical has always insisted on independent R \& D and innovation. Mindray invested $10 \%$ of revenue every year to carry out R \& D. In 2018, Mindray took out $10.33 \%$ of its total revenue and applied it to R \& D investment. As of the end of 2018, Mindray has applied for 3989 patents and authorized 2742 patents, ranking first in the list of Chinese medical device companies. Since 2000, Mindray has made breakthroughs in core technology. At this time, the technology of medical ultrasound equipment has matured. Analog black-and-white ultrasound is the leading product in the mainstream market. Multinational companies have an extensive research and development system for analog systems, and the cost of developing new system products is high. Mindray pointed out that the combination of digital technology and ultrasonic technology can significantly reduce costs and started the ultrasonic testing project after obtaining the first venture investment from the Walden Group. In 2001, Mindray successfully launched the first all-digital desktop black and white super device (DP-9900) on the market at that time. Due to the reasonable cost-effectiveness, the products entered the Notre Dame market.

The portable all-digital black and white super is Mindray's reverse innovation product in the stage of improvement and innovation. At this stage, Mindray has accelerated the development of its products, in order to help Mindray understand the cutting-edge development trend of international science and technology and master the core technology. In 2002, Mindray and the Chinese Ministry of Science and Technology jointly established the National Medical Diagnostic Instrument Engineering Center. In 2004, Mindray found that the domestic maternal and child health care system needed portable ultrasound products, and information from overseas agents showed that the same needs existed in Notre Dame's private clinics and small private hospitals. Based on the DP-9900 technology platform, Mindray has developed a portable all-digital black and white ultrasonic instrument.

M7 portable color Doppler and AED are Mindray's reverse innovation products at the stage of independent innovation. In 2008, Mindray and Fujitsu carried out strategic cooperation in the field of radiation to improve and enhance their technical strength and market competitiveness in the field of radiation X-ray photography systems. In 2006, China conducted research and development based on the first low-level all-digital color Doppler DC-6 with independent intellectual property rights. In 2010, they overcame the global technical problems of notebook color Doppler ultrasound, such as "power consumption, heat dissipation, and volume." They developed the high-end ultrasound instrument M7 portable color Doppler ultrasound (to meet the daily clinical, operating room, intensive care, on-site rescue and another ultrasonic medical diagnosis), Hair cooperation with multinational companies and fierce market competition. In 2013 Mindray developed the first domestic automatic external defibrillator AED. Behind this, Mindray 
experienced 13 years of core technology research and development of defibrillation, and finally broke the blockade of more than 1,000 patents by international giants.

Today, Mindray AED accounts for more than $20 \%$ of the Chinese market, and its products are sold to more than 100 countries and regions. Since 2015, Mindray has surpassed Siemens Medical in sales in the ultrasound field, ranking third. In the field of guardianship, Mindray has ranked first two in the world. In 2016, Boston Consulting selected 100 companies from emerging markets around the world that are accelerating globalization. Mindray became the only "global challenger" in the field of medical technology. 50\% of more than 230 self-developed medical devices are sold to more than 190 countries and regions abroad. Mindray's penetration rate in some countries is already very high. Taking the Indian market as an example, Mindray has set up 4 branches in India and has a work team of hundreds of people. This effort has led to nearly $70 \%$ of hospitals in India using Mindray's products. In 2017 Mindray independently developed the world's first mid-range anesthesia-WATOPro anesthesia machine equipped with a fully electronic flow meter. Its main features are as follows: standard electronic flowmeter, 15.1-inch high-resolution touch screen, and a new Optimizer TM technology platform.

\section{Conclusions and Policy Implications}

This article takes Huawei, Galanz and Mindray in the Chinese high-tech industry as examples of reverse innovation research in emerging markets. It discusses the experience and lessons of reverse innovation in each stage of the company's development from the time dimension. The following conclusions can be drawn: (1) The market. For latecomers in emerging countries, the first market to expand is the emerging market. This is conducive to further tapping the local market of enterprises and is also conducive to the expansion of developed countries and even the global market through reverse innovation technology. (2) Technology. Independent innovation capability is the key to reverse innovation. High-tech companies should increase their investment in research and development. Enterprises should actively introduce new technologies and strive to improve their independent innovation capabilities. (3) Support from national policies. The state should subsidize high-tech enterprises. This will reduce their pressure on expanding their markets and conducting $\mathrm{R} \& \mathrm{D}$. Therefore, the state should introduce more policies to encourage enterprise innovation. Enterprises should also actively use resources and seek more space for development.

\section{References}

[1] Danguy, J. (2017) 'Globalization of innovation production: A patent-based industry analysis', Science and Public Policy. doi: $10.1093 / \mathrm{scipol} / \mathrm{scw} 025$.

[2] Son Thi Kim Le (2019) 'Innovation efforts in developing countries: The case of Vietnamese small and medium-sized enterprises', WIDER Working Paper, 7. doi: 10.35188/UNU-WIDER/2019/641-8.

[3] Jäger, J. and Springler, E. (2019) 'Emerging Market Multinationals and European Economic Developments', in Emerging Market Multinationals and Europe. doi: 10.1007/978-3-030-31291-6_4.

[4] Hadengue, M. and Warin, T. (2014) 'Patterns of Specialization and (Un)conditional Convergence: The Cases of Brazil, China and India', Management international. doi: 10.7202/1027869ar.

[5] Trimble, C. (2012) 'Reverse innovation and the emerging-market growth imperative', Ivey Business Journal.

[6] Qin Jian (2011) 'Organizational Learning, Technical Cooperation and Multinational Corporations' Breakthrough Innovation in China ', Journal of Management, 11.

[7] Friedman, T. L. (2012) 'China Needs Its Own Dream', New York Times.

[8] Hennart, J. F. (2018) 'Springing from where? How emerging market firms become multinational enterprises', International Journal of Emerging Markets. doi: 10.1108/IJoEM-09-2017-0324.

[9] Gwarda-Gruszczyńska, E. (2016) 'Reverse Innovation and Intercultural Management Aspects', Journal of Intercultural Management. doi: 10.1515/joim-2016-0010.

[10] Kardes, I. (2016) 'Reaching middle class consumers in emerging markets: Unlocking market potential through urban-based analysis', International Business Review. doi: 10.1016/j.ibusrev.2016.03.005.

[11] Hadengue, M. et al. (2017) 'Avoiding the Pitfalls of Reverse Innovation', Research-Technology Management. doi: 10.1080/08956308.2017.1301002.

[12] Tiwari, R. and Herstatt, C. (2012) 'Technology and Innovation Management Frugal Innovations for the "Unserved" Customer: An Assessment of India' s Attractiveness as a Lead Market for Cost-effective Products', Journal of Indian Business Research.

[13] Cortonesi, P., Cahen, F. R. and Borini, F. M. (2019) 'Reverse open innovation: Open innovation as a relevant factor for reverse innovation', International Journal of Innovation and Learning. doi: 10.1504/IJIL.2019.100523.

[14] Brem, A. and Ivens, B. (2013) 'Do Frugal and Reverse Innovation Foster Sustainability? Introduction of a Conceptual Framework', Journal of Technology Management for Growing Economies. doi: 10.15415/jtmge.2013.42006.

[15] Hadengue, M., de Marcellis-Warin, N. and Warin, T. (2017) 'Reverse innovation: a systematic literature review', International Journal of Emerging Markets. doi: 10.1108/IJoEM-12-2015-0272.

[16] Govindarajan, V. (2012) 'A reverse-innovation playbook', Harvard Business Review.

[17] He Ying (2015) "Reverse Innovation: A New Strategy for Enterprise Competition", "China Industry Review", 05.

[18] Govindarajan, V. and Ramamurti, R. (2014) 'Reverse innovation, emerging markets, and global strategy', IEEE Engineering Management Review. doi: 10.1109/emr.2014.6823812. 
[19] Von Zedtwitz, M. et al. (2015) 'A typology of reverse innovation', Journal of Product Innovation Management. doi: 10.1111/jpim.12181.

[20] OECD/Eurostat (2018) Oslo Manual 2018: Guidelines for Collecting, Reporting and Using Data on Innovation, 4th Edition, The Measurement of Scientific, Technological and Innovation Activities, OECD Publishing, Paris/Eurostat, Luxemburg. doi: 10.1787/9789264304604-en.

[21] Jandhyala, S. and Phene, A. (2015) 'The Role of Intergovernmental Organizations in Cross-border Knowledge Transfer and Innovation*', Administrative Science Quarterly. doi: $10.1177 / 0001839215590153$

[22] Immelt, J. R., Govindarajan, V. and Trimble, C. (2009) 'How GE is disrupting itself', Harvard Business Review.

[23] Govindarajan, V. and Trimble, C. (2012) 'Reverse innovation: a global growth strategy that could pre-empt disruption at home', Strategy \& Leadership. doi: $10.1108 / 10878571211257122$.

[24] Govindarajan, V. and Ramamurti, R. (2011) 'Reverse innovation, emerging markets, and global strategy', Global Strategy Journal. doi: 10.1002/gsj.23.

[25] Corsi, S. and Di Minin, A. (2014) 'Disruptive innovation in reverse: Adding a geographical dimension to disruptive innovation theory', Creativity and Innovation Management. doi: 10.1111/caim.12043.

[26] Zeschky, M. B., WinterhalterProf, S. and Gassmann, O. (2014) 'From cost to frugal and reverse innovation: Mapping the field and implications for global competitiveness', Research Technology Management. doi: 10.5437/08956308X5704235.

[27] Xing Xiaoqiang, Ge Hufei, Tong Yunhuan (2016) "Analysis of the Concept of Reverse Innovation, Path Division and Research Framework", "Research Management", 10.

[28] Wei Jinde (2017) Research on reverse innovation model of high-tech enterprises. Guangxi University

[29] Sharma, A. and Iyer, G. R. (2012) 'Resource-constrained product development: Implications for green marketing and green supply chains', Industrial Marketing Management. doi: 10.1016/j.indmarman.2012.04.007.

[30] Sharma, A. and Jha, S. (2016) 'Innovation from emerging market firms: what happens when market ambitions meet technology challenges?', Journal of Business and Industrial Marketing. doi: 10.1108/JBIM-12-2014-0265.

[31] Bottles, K. (2012) 'Reverse innovation and American health care in a time of cost crisis.', Physician executive.

[32] Lim, C., Han, S. and Ito, H. (2013) 'Capability building through innovation for unserved lower end mega markets', Technovation. doi: 10.1016/j.technovation.2013.06.010.

[33] Sinha, R. (2013) 'Reverse Innovation: A Gift from Developing Economy to Developed Economy', Business Perspectives and Research. doi: 10.1177/2278533720130106.

[34] Corsi, S., DiMinin, A. and Piccaluga, A. (2014) 'Reverse innovation at speres a case study in China', Research Technology Management. doi: 10.5437/08956308X5704215.

[35] Rosca, E., Arnold, M. and Bendul, J. C. (2017) 'Business models for sustainable innovation - an empirical analysis of frugal products and services', Journal of Cleaner
Production. doi: 10.1016/j.jclepro.2016.02.050.

[36] Zhu, F., Zou, S. and Xu, H. (2017) 'Launching reverse-innovated product from emerging markets to MNC's home market: A theoretical framework for MNC's decisions', International Business Review. doi: 10.1016/j.ibusrev.2016.06.003.

[37] Martin, L.(2018) 'Drivers of Reverse Innovation', 2018 IEEE International Conference on Engineering, Technology and Innovation (ICE/ITMC), doi: 10.1109/ICE.2018.8436367.

[38] Koch, C. (2017) 'Reduction or revaluing in cost constrained design? Reverse innovation conceptualized', in Association of Researchers in Construction Management, ARCOM - 33rd Annual Conference 2017, Proceeding.

[39] Woodside, A. G. and Wilson, E. J. (2003) 'Case study research methods for theory building', Journal of Business and Industrial Marketing. doi: 10.1108/08858620310492374.

[40] Creswell, J. W. (2013) Qualitative Inquiry and Research Design, Qualitative Inquiry and Research Design.

[41] Sergio Biggemann (2010) 'Chapter 3 Modeling the structure of business-to-business relationships', in Organizational Culture, Business-to-Business Relationships, and Interfirm Networks, pp. 22-177.

[42] Patnaik, S. and Pandey, S. C. (2019) 'Case Study Research', in Methodological Issues in Management Research: Advances, Challenges, and the Way Ahead. doi: 10.1108/978-1-78973-973-220191011.

[43] Stavros, C. and Westberg, K. (2009) 'Using triangulation and multiple case studies to advance relationship marketing theory', Qualitative Market Research. doi: $10.1108 / 13522750910963827$.

[44] Qiu Li (2020) 'China Economic Annual Report 2019 has many highlights: the domestic market is expected to become the world's first', China News Service, 17 January. Available at: $\quad$ http://www.oushinet.com/china/chinanews/20200117 /339227.html

\section{Biography}

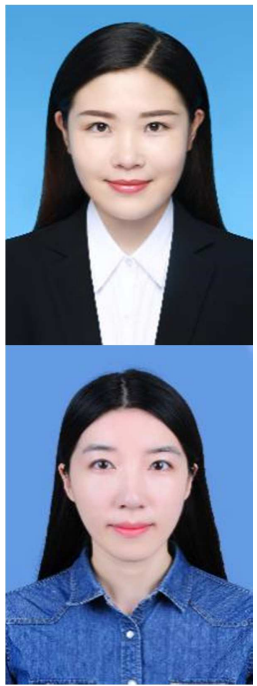

Xiaomei Han, (1996-), female, Qingdao, Shandong, master student, engaged in industrial economics and regional development research, China University of Petroleum (East China) School of Economics and Management.

Shanshan Liu, (1996-), female, Heze, Shandong, master student, engaged in industrial economics and regional development research, China University of Petroleum (East China) School of Economics and Management. 